\title{
Taxonomic key to the snakes (Squamata: Ophidia) species of the Itajaí Valley, Santa Catarina, Brazil
}

\author{
Camilla Spengler Waltrick ${ }^{1}$ \& Luís Olímpio Menta Giasson ${ }^{2}$
}

\author{
1 Universidade Regional de Blumenau (FURB), Programa de Pós-Graduação em Biodiversidade (PPGBI0). Blumenau, SC, Brasil. \\ ORCID: http://orcid.org/0000-0002-6750-5842. E-mail: camilla.waltrick@hotmail.com \\ 2 Universidade Regional de Blumenau (FURB), Departamento de Ciências Naturais. Blumenau, SC, Brasil. \\ ORCID: http://orcid.org/0000-0002-3967-9650. E-mail: Igiasson@furb.br
}

\begin{abstract}
Snakes represent the richest Reptile group in Brazil, amounting to 412 species and $40 \%$ of them are endemic for the country. This great richness combined with the poor taxonomic knowledge makes the identification a difficult process. To correctly identify a specimen, guides, taxonomic revisions, identification keys, and consulting specialists are the most used methods. Identification keys are based on separation and segregation of characters, where the chosen paths lead to the appropriate taxa. These tools are normally used by students and non-taxonomists. Also, they can be very helpful with the general public, where they can identify the species with simple characters. This study aims to develop keys for the snakes from the State of Santa Catarina state, Brazil, focusing on the Itajaí Valley species. We surveyed 351 specimens deposited in Universidade Regional de Blumenau Zoological Collection (CZFURB), Universidade Federal de Santa Catarina (CHUFSC), and Natural History Museum of Capão da Imbuia (MHNCI) herpetological collections. Characters including pholidosis, dentition, and coloration patterns were examined from the 46 snake species registered from Itajaí Valley.
\end{abstract}

Keywords. Biodiversity; Pholidosis; Taxonomy; Squamata.

\section{INTRODUCTION}

Snakes have a major number of species among the Brazilian reptiles (Costa \& Bérnils, 2018). With 412 species, this represents more than $50 \%$ of the total amount (Nogueira et al., 2020). This abundance ranks Brazil in third place of countries with most reptile species (Uetz et al., 2020). To study some species or deposit it in a zoological collection, first, it is necessary the correct identification of the animal (Papavero, 1994). There is a variety of options to correctly identify any species, the most used are consulting specialists, bibliography, taxonomic keys, and surveillance in biological collections (Ferrarezzi \& Monteiro, 2001). Taxonomic keys are based on separation and segregation of characters, in a way that the choices lead to the correct identification (Papavero, 1994). These tools are normally used by students, also, they can be helpful for non-taxonomists or the general public (Di Nicola, 2019). There are few books (Peters \& Orejas-Miranda, 1970; Dixon et al., 1993; Quintela \& Loebmann, 2009; Bernarde, 2014), journal articles (Dixon, 1989; Zaher et al., 2008; Passos et al., 2009; Abegg et al., 2016), monographs (Di-Bernardo, 1992) and non-published works (Ferrarezzi \& Monteiro, 2001) providing keys for Brazilian species, yet, most of them are outdated. For the state of Santa Catarina, the studies about snakes are based on records of geographic distributions (Fortes et al., 2010; Kunz et al., 2011), chromatic anomalies (Sueiro et al., 2010), field guides (Oliveira et al., 2020) and surveys in zoologic collections (Bérnils et al., 2001; Althoff, 2014). Bérnils et al. (2001) listed 46 species of snakes for the Itajaí Valley region; however, they provided no identification keys for such species. Thus, this study aims to develop identification keys for species of snakes from Itajaí Valley.

\section{MATERIAL AND METHODS}

\section{Study region}

The Itajaí Valley is located in the state of Santa Catarina, southern Brazil, between the latitudes $26^{\circ} 27^{\prime} \mathrm{S}$ and $27^{\circ} 53^{\prime} \mathrm{S}$ and longitudes $48^{\circ} 38^{\prime} \mathrm{W}$ and $50^{\circ} 29^{\prime} \mathrm{W}$. Its total area amounts to $15.000 \mathrm{~km}^{2}$ and includes 55 municipalities (Aumond et al., 2018) (Fig. 1). 


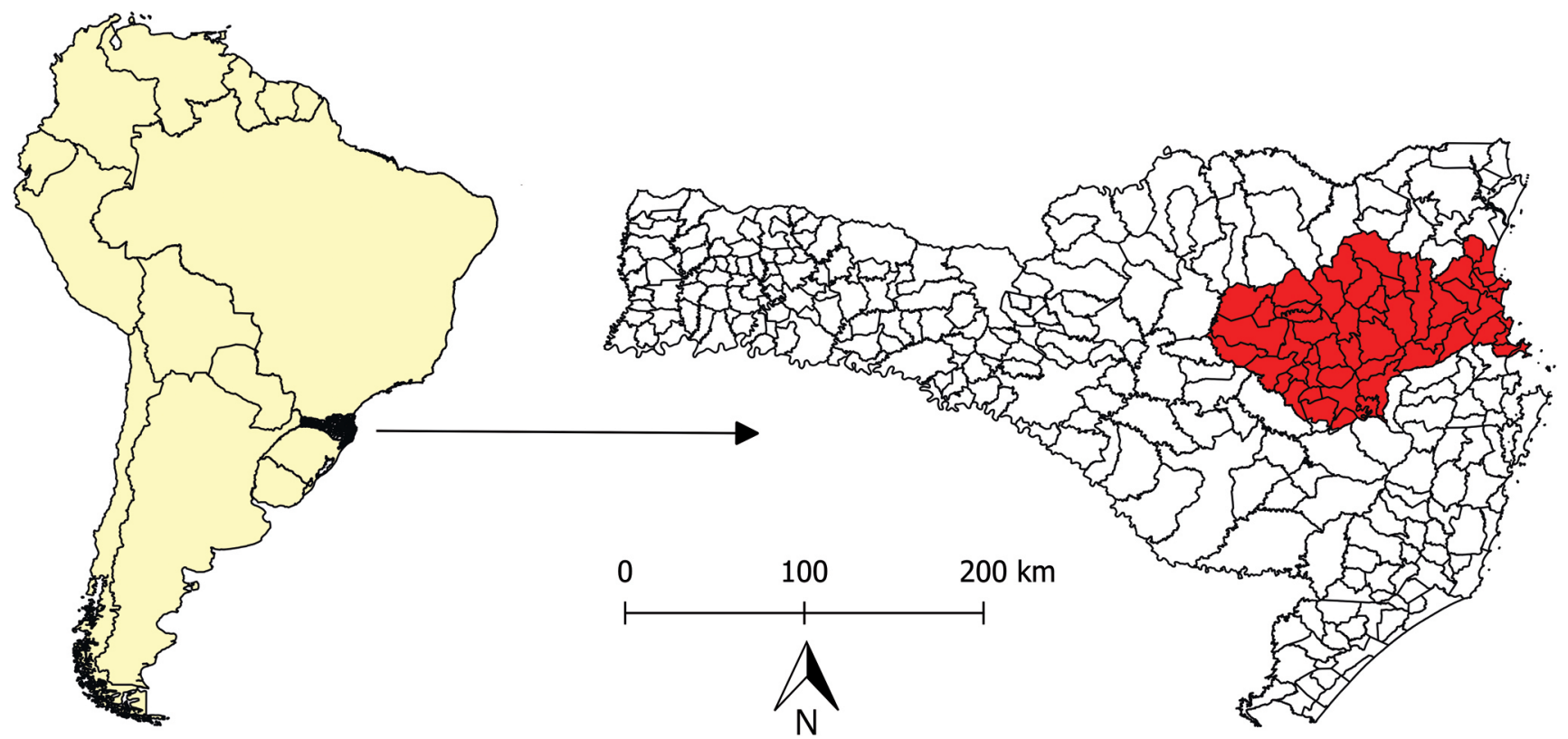

Figure 1. Map of the Itajaí Valley location.

\section{Data Collection}

We listed 46 species from Itajaí Valley, based on Bérnils et al. (2001) and surveyed the Zoologic Collection of the Universidade Regional de Blumenau (CZFURB), Blumenau, Santa Catarina, Brazil; Herpetological Collection of the Museu de História Natural Capão da Imbuia (MHNCI), Curitiba, Paraná, Brazil and Universidade Federal de Santa Catarina (UFSC, CHUFSC), Florianópolis, Santa Catarina, Brazil. Characters including pholidosis and color patterns were analyzed. Scale counting follow Dowling (1951) and Dixon \& Kofron (1983) for Liotyphlops beui (Amaral, 1924).

\section{Species identifications}

We followed the nomenclature of Costa \& Bérnils (2018) and nomenclatural modifications posterior to this publication, like the transfer of Mastigodryas bifossatus (Raddi, 1820) to the genus Palusophis (Montingelli et al., 2019) and synonymization, such as Sibynomorphus with Dipsas (Arteaga et al., 2018), and Uromacerina ricardinii (Peracca, 1897) with Cercophis auratus (Schlegel, 1837). The bibliography used for the identification of the specimens is listed in Table 1, Appendix I.

\section{RESULTS AND DISCUSSION}

We examined 351 specimens housed in the collections. The specimens were predominantly from the State of Santa Catarina and Itajaí Valley (Appendix II). Due to the species distribution, some records might have been unavailable for the region. Also, to complement the database, some specimens from other states were included in this study, since they are known to occur in the Itajaí Valley.

\section{Taxonomic key}

The key is mainly based on the count of scale rows around the neck, mid-body, and near the cloaca. Examination of dentition, head shields, number of ventral and subcaudal scales, and the condition of dorsal scales (smooth, keeled, or with apical pits) (Fig. 2) are other characters used. Color patterns were only used in cases where one or more pholidosis values were analogous between species. "Background color" indicates the color between dorsal rings, marks, and bands (Di Nicola, 2019). "Rings" refers to a circular band, which surrounds both dorsal and ventral scales "bands" refers to transverse markings on the body (Rasmussen et al., 2011). Thus, the key is accompanied by figures to aid the identification process.
A

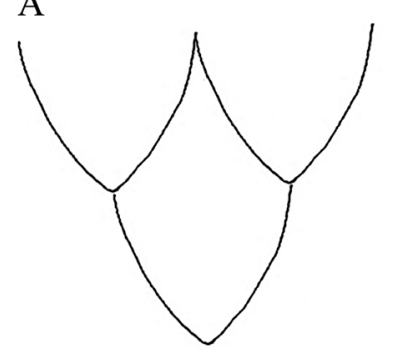

C

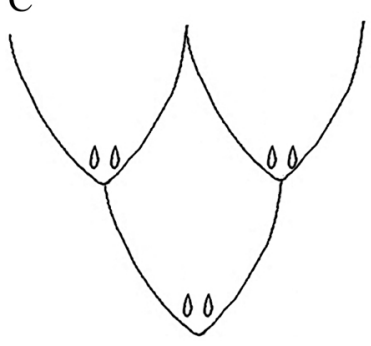

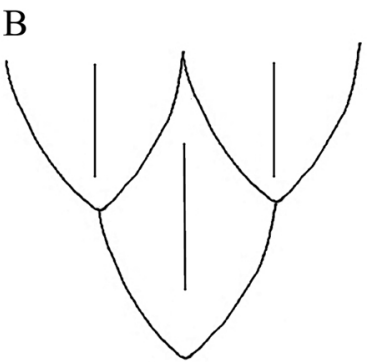

$\mathrm{D}$

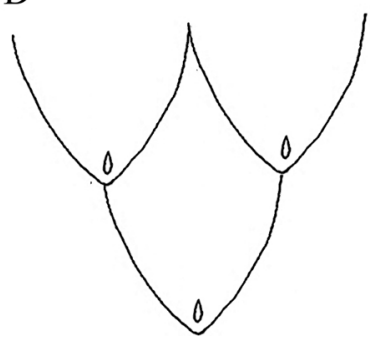

Figure 2. Overview of dorsal scales (A) smooth (B) keeled (C) with two apical pits (D) with one apical pit. 


\section{Key to the snake species of Itajaí Valley}

1. Dorsal and ventral scales indistinct (Fig. 3A)

Liotyphlops beui

- Dorsal and ventral scales distinct (Fig. 3B) .

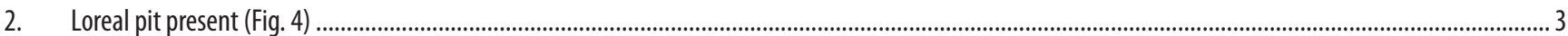

- Loreal pit absent

3. Presence of rattle at the tip of the tail

Crotalus durissus Linnaeus, 1758

- Absence of rattle at the tip of the tail

4. Proteroglyphous dentition (Fig. 5A)

- Aglyph or opistoglyph dentition (Fig. 5B-C)

Bothrops neuwiedi Wagler, 1824

Supralabials with large white blotches; dorsum with trapezoidal shapes outlined by white lines

- Supralabials without blotches; dorsum with triangular shapes.

6. Inverted-v dorsal shapes poorly outlined that eventually merge in the vertebral row of scales. The area occupied by the space between the dorsal shapes is about 1,5-2 times bigger than the shapes

Bothrops jararaca (Wied, 1824)

- Triangular dorsal shapes highly outlined, without merging in the vertebral row. The area occupied by the space between the dorsal shapes is similar to the size of the dorsal shapes

7. Black dorsal rings grouped in triads (Fig. 6A) Bothrops jararacussu Lacerda, 1884

- Black dorsal rings in monads (Fig. 6B) Micrurus altirostris (Cope, 1859)

8. Dorsal rows even in the mid-body. Micrurus corallinus (Merrem 1820)

- Dorsal rows odd in the mid-body

9. Anal plate single

- Anal plate divided.

10. Subcaudals single

- Subcaudals paired

11. Black/dark brown coloration, dorsal rows 10-10-08.

- Black and yellow coloration, dorsal rows 16-16-10

12. More than 300 ventrals + caudals.

- Less than 300 ventrals + caudals

Pseudoboa haasi (Boettger, 1905)

13. Dorsals $12-12-10$ or $12-10-10$, dorsal pattern dark green, two dark dorsal stripes with a lighter stripe between them (co preserved specimens)

Chironius laevicollis (Wied, 1824)

..Spilotes pullatus (Linnaeus, 1758)

Chironius foveatus Bailey 1955

Dorsals 12-10-08, dorsal pattern uniform olive green and/or brown, without a vertebral stripe Chironius bicarinatus (Wied, 1820)

14. Anal plate single

Chironius exoletus (Linnaeus, 1758)

- Anal plate divided

15. Dorsal rows 15 at mid body.

- Internasals paired

17. Dorsal rows in $17-15-15$ or $16-15-15$

Dipsas albifrons (Sauvage, 1884)

- Dorsal rows in 15-15-15.

18. Dorsal pattern with black rings

- Dorsal pattern uniform or with a white nuchal collar...

Clelia plumbea (Wied, 1820)

19. Dorsum with white and/or red background, and black rings (background can be yellowish in preserved specimens). Dorsal rings invade the ventral scales (Fig. 8A). Oxyrhopus clathratus Duméril, Bibron \& Duméril, 1854

20. Dorsum brow, black or dark-grey, with a reticulated pattern Atractus reticulatus (Boulenger 1885)

- Dorsum with clearly defined blotches

21. Belly with dark brown large blotches (Fig. 7A)

- Belly dotted and/or with dark brown small blotches (Fig. 7B)

22. Dorsal scale rows in 19-19-17

- Dorsal scale rows in 19-19-19 or 17-17-15.

23. Dorsal scale rows with reduction..

- Dorsal scale rows without reduction.

24. Dorsal scales keeled..

25. Dorsal rows 19-19-19 
..Philodryas aestiva (Duméril, Bibron \& Duméril, 1854)

28. Color pattern emerald green uniform (color pattern can change to blue in preserved specimens)

Thamnodynastes hypoconia (Cope, 1860)

- Color pattern light brown and checkered

Philodryas olfersii (Lichtenstein, 1823)

29. Dorsum with green unicolor pattern (color pattern can change to blue in preserved specimens)

Philodryas patagoniensis (Girard, 1858)

Dorsum olive-green, light brown or greenish-grey, base and tip of the scales outlined by black color

30. Number of subcaudals: 100 or more

- Number of subcaudals: $<100$.

31. Dorsal rows 15-15-11 or 15-13-11.

Dendrophis aurata Schlegel, 1837

- Dorsal rows 21-21-17 or 19-19-15.

32. Scales with apical pits

- Scales without apical pits

Erythrolamprus miliaris (Linnaeus, 1758)

33. Dorsal rows 21-21-17. Tropidodryas striaticeps (Cope, 1870)

- Dorsal rows 19-19-15

Thamnodynastes strigatus (Günther, 1858)

34. Dorsal rows 21 at mid-body..... Xenodon neuwiedii Günther, 1863

- Dorsal rows 19 or 17 at mid-body

35. Dorsal rows 19-19-17. Xenodon merremii (Wagler in Spix, 1824)

- Dorsal rows 19-19-15 or 17-17-15.

36. Dorsal pattern greenish brown or golden-brown uniform, with two dark dorsal stripes.

Gomesophis brasiliensis (Gomes, 1918)

- Dorsal pattern checkered, banded or with scattered blotches

37. Dorsal rows 17-17-15 Tomodon dorsatus Duméril, Bibron \& Duméril, 1854

- Dorsal rows 19-19-15.

38. Yellowish mark on top of the head, shaped as "U", " $X$ ", " $Y$ " or " $W$ "

- Top of the head uniform, without marks Erythrolamprus almadensis (Wagler in Spix, 1824)

39. Dorsal rows 15-15-15 ...Erythrolamprus poecilogyrus (Wied, 1824)

- Dorsal rows 17-17-17.

40. Black head, white nuchal collar, vertebral zone red colored, ventral and pleural zones black colored

- Brown head with a post-orbital stripe, dorsal bands shaped like an hourglass; . rectangular.

41. > 130 Subcaudal scales

- $<130$ Subcaudal scales

42. Dorsum bright green, with a copper vertebral stripe, belly red colored.

Phalotris reticulatus (Peters, 1860) ..the tail is darker and the bands are Palusophis bifossatus (Raddi, 1820) Imantodes cenchoa (Linnaeus, 1758)

- Dorsum brown, without a copper vertebral stripe..

43. A well-defined line along the canthus rostralis, ranging from the snout to the postoculars

- Without a well-defined line along canthus rostralis, postocular region may present a poorly defined light band.

44. $<140$ ventral scales

- $>140$ ventral scales

Erythrolamprus jaegeri (Günther, 1858)

5. Body with a wavy yellowish lateral line; two parallel bright yellow circular blotches isolated in the nuchal region coming from the lateral stripe Echinanthera undulata Wied (1824)

- Body with a straight lateral line outlined with small yellow dotted lines; Lateral line color light brown; two bright yellow parallel circular blotches in the nuchal region merging with the color of supralabials and ventral scales.

Echinanthera cyanopleura Cope (1869)

The compiled species are represented by five families, with Dipsadidae amounting to the major number of species (33), followed by Colubridae (6), Viperidae (4), Elapidae (2), and Anomalepididae (1).

\section{Family Anomalepididae Taylor, 1939}

Only one species of this family occurs in the region (Bérnils et al., 2001). Liotyphlops beui can be recognized by the indistinct dorsal and ventral scales; they are all cycloids and have the same size (Dixon \& Koffron 1983).

\section{Family Colubridae Oppel, 1811}

For the Vale do Itajaí the species of the genera Chironius and Spilotes can be recognized by the even number of scale rows (Amaral, 1929; Dixon et al., 1993, and Palusophis bifussatus by its body coloration and 15 scale rows at mid-body (Montingelli et al., 2019).

\section{Family Elapidae Boie, 1827}

Members of this family show proteroglyphous dentition and the absence of a loreal scale Ferrarezzi (1994). The American elapids carry a body coloration composed of shades of yellow, black, white, and red, outlined by black or dark-brown rings or blotches (Campbell \& Lammar, 2004).

\section{Family Dipsadidae Bonaparte, 1838}

This family stands as a monophyletic group (Zaher et al., 2009), but with a high number of unsupported clades within its subfamilies (Zaher et al., 2019). It is di- 
vided into 14 tribes and 18 genera classified as incertae sedis (Zaher et al., 2009).

\section{Dendrophis aurata Schlegel, 1837}

This species does not belong to any tribe, therefore being classified as incertae sedis (Zaher et al., 2009). Dendrophis aurata can be distinguished from the oth-
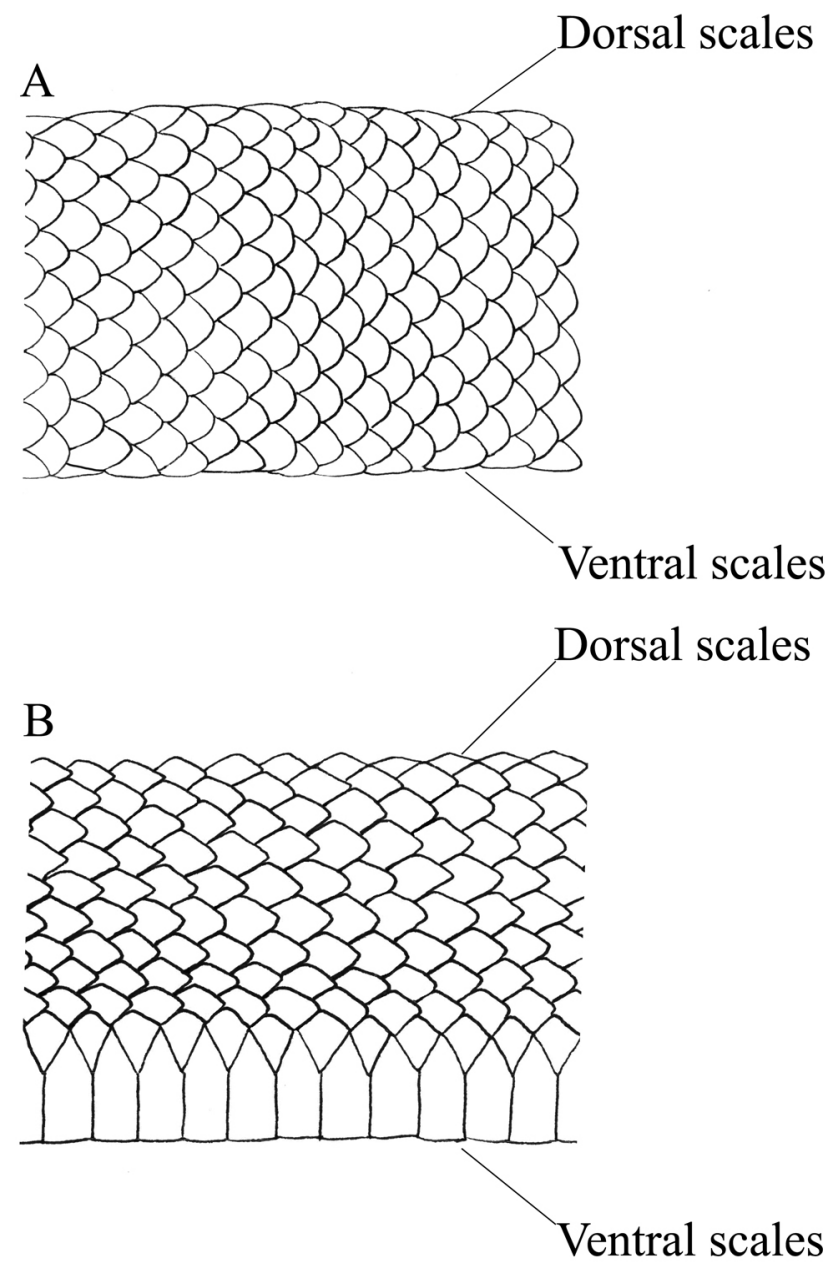

Figure 3. Lateral view of a general snake: $(A)$ indistinct dorsal and ventral scales (B) distinct dorsal and ventral scales.

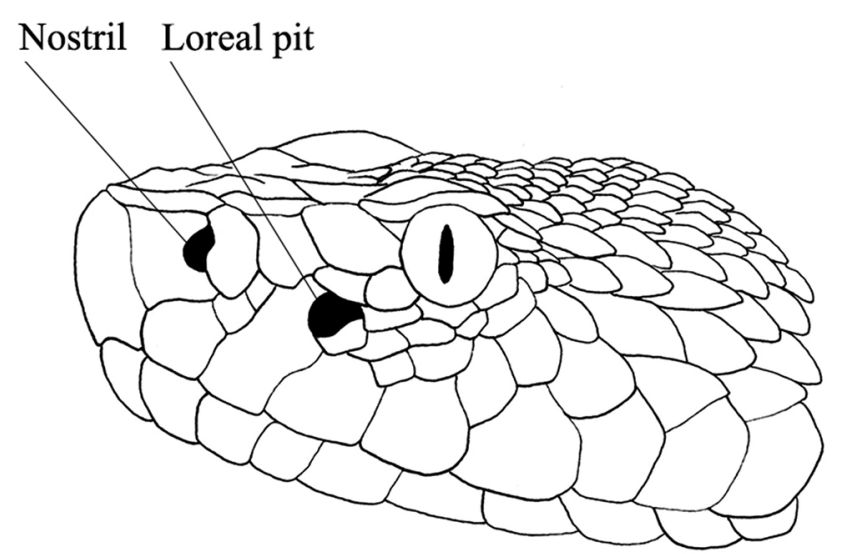

Figure 4. Lateral view of the head of a general Viperidae, showing the loreal pit. er species by showing dorsal scale rows in 17-15-13, 15-15-11, or 15-13-11 (Hoge, 1957; Hoogmoed et al., 2019).

\section{Tribe Hydropsini Dowling, 1975}

Externally, this tribe can be recognized by the eyes and nostrils directed to the top of the head (Costa et al., 2016), single internasal scale, divided anal plate, and partially or entirely keeled dorsal scales (Peters \& OrejasMiranda 1970).

\section{A}

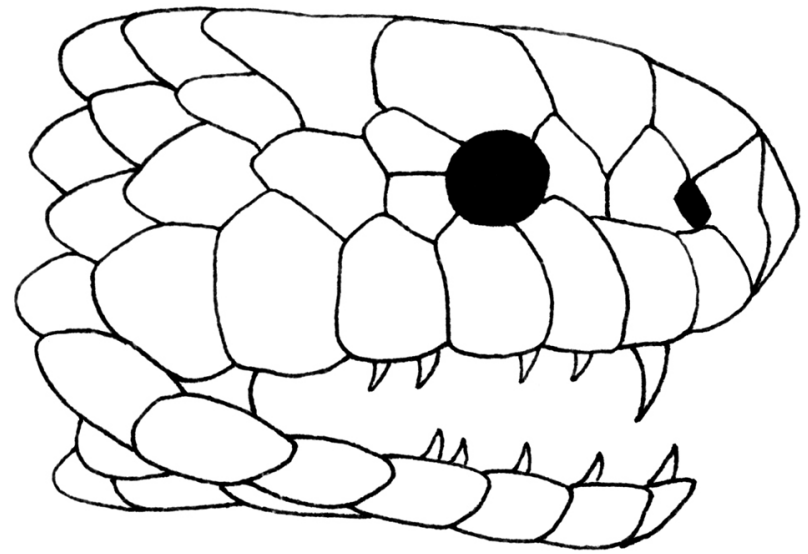

$\mathrm{B}$

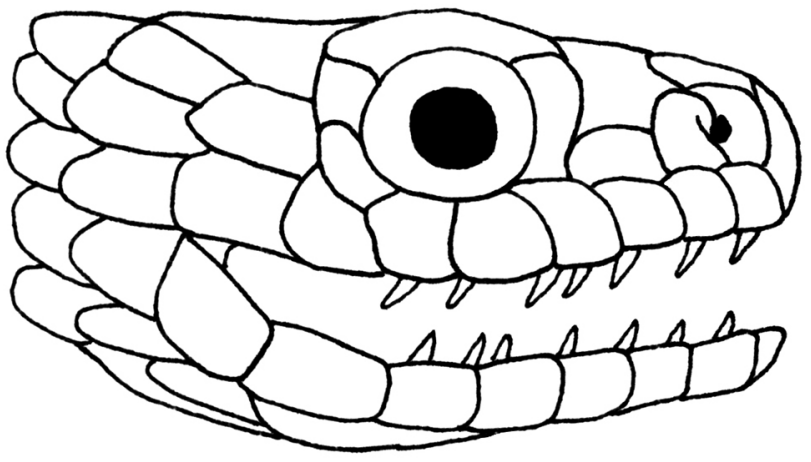

Q

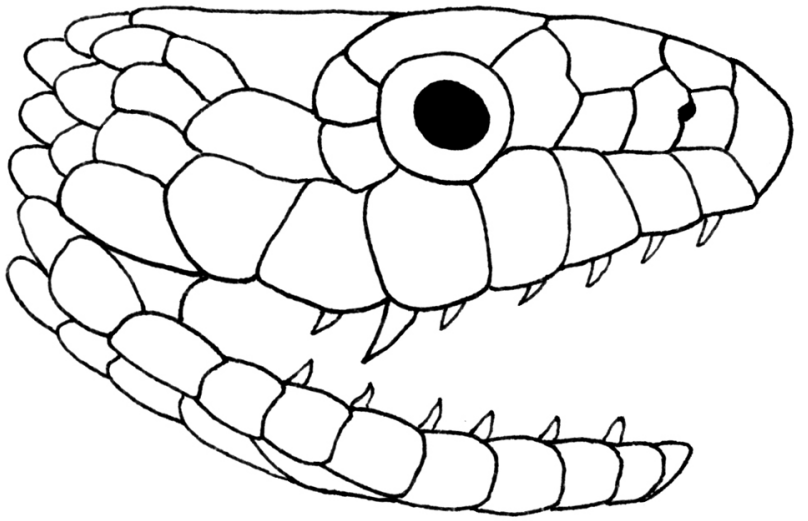

Figure 5. Lateral view of general snake heads showing different dentitions (A) proteroglyph (B) aglyph and (C) opistoglyph. 


\section{Tribe Philodryadini Cope, 1886}

Zaher et al. (2009) designed a putative synapomorphy for this tribe, that the body of the hemipenis is bigger than the lobes, with the non-sulcated face covered almost entirely by two lines of enlarged chalices. In the Itajaí Valley, Philodryas is the only genus from this tribe (Bérnils et al., 2001). The species are recognized by their slender body, round pupil, posterior reduction of dorsal scales rows, and opistoglyphous dentition (Vanzolini, 1980; Quintela \& Loebmann, 2009).

\section{Tribe Tropidodryadini Zaher et al., 2009}

Members from this tribe have a bi-calyculate and non-capitated hemipenis, with calycular regions directed laterally and intrasulcal area with two lines of enlarged spines (Zaher et al., 2009). This tribe is composed only by the sister species Tropidodryas serra (Schlegel 1837) and Tropidodryas striaticeps (Cope 1870). They share the following characters: dorsal scale rows in 21-21-17, 8-9 supralabials, 10 infralabials, and $3+3$ post-oculars (Thomas \& Dixon, 1977).

\section{Tribe Dipsadini Bonaparte, 1838}

In the Itajai Valley, Atractus and Dipsas are the representant genera of this tribe. Recently occurred the synonymization of Sibynomorphus with Dipsas (Arteaga et al., 2018), however, this change can still be premature (Zaher et al., 2019). Atractus reticulatus can be distinguished by its tribe members by the dorsal rows 15-15-15, smooth scales, dorsum with reticulated pattern, and venter immaculate (Passos et al., 2010). Dipsas species can be distinguished from Atractus by the following characteristics: dorsal formula $17-15-15$ or $16-15-15$ for Dipsas albifrons and 15-15-15 with dorsal pattern with clearly defined blotches for Dipsas neuwiedi and $D$. ventrimaculata (Peters \& Orejas-Miranda, 1970).

\section{Tribe Echinantherini Zaher et al., 2009}

This tribe is represented by the genera Echinanthera and Taeniophallus (Zaher et al., 2009), they have hemipenis unilobed and uni capitate. Sulcus spermaticus is divided relatively distally in the calyculate area, and there

A

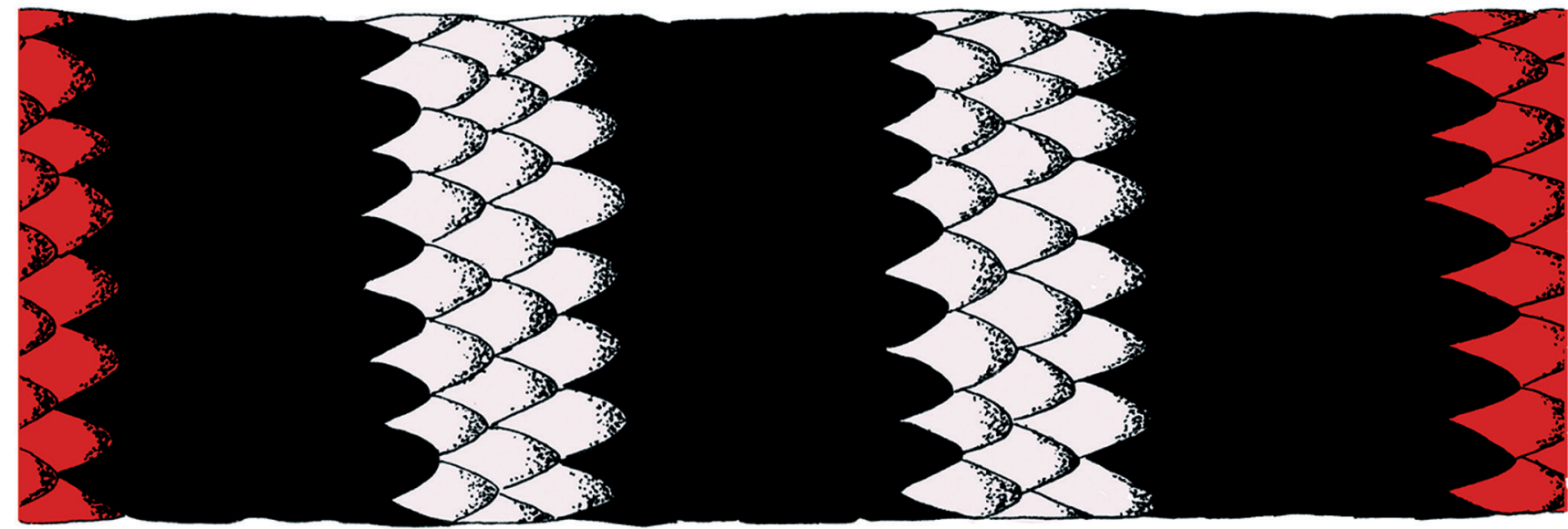

\section{$\mathrm{B}$}

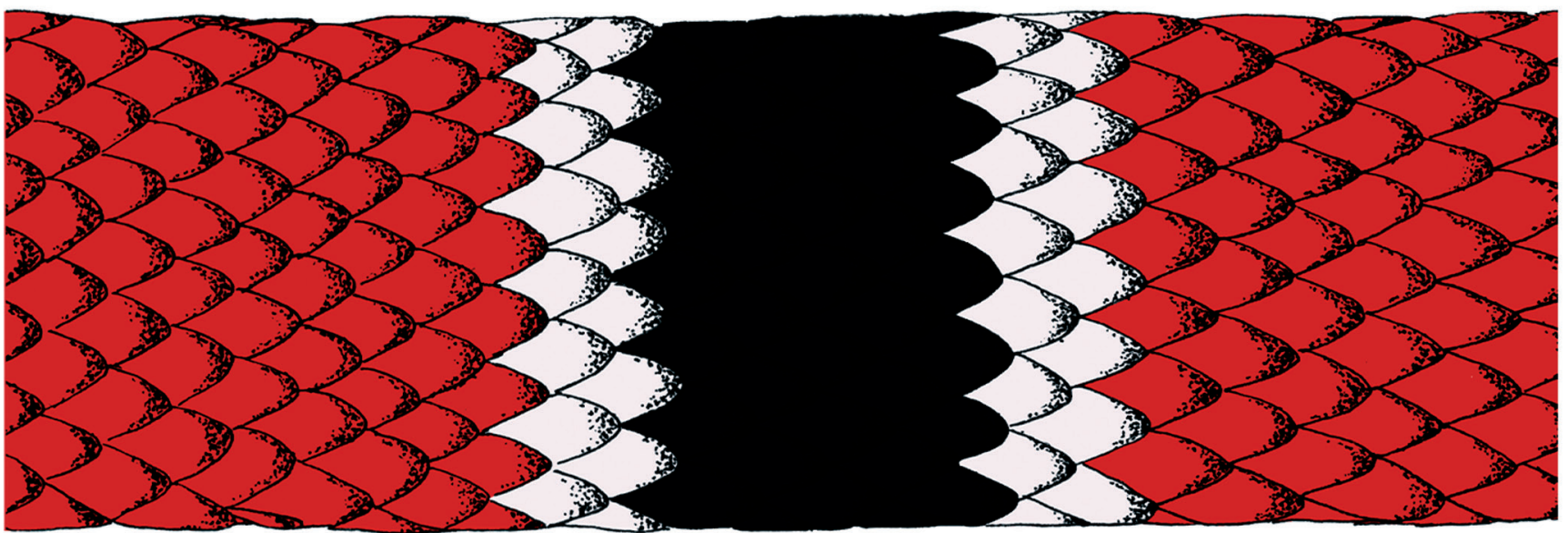

Figure 6. Comparative lateral view of coral snakes midbody: (A) Micrurus altirostris (Cope 1859), showing rings grouped in triads and (B) Micrurus corallinus (Merrem 1820) showing rings grouped in monads. 
is a large nude area in the asulcate side of the hemipenial body (Zaher et al., 2009). Both genera are morphologically similar, with a slender body, aglyphous dentition, and circular pupils (Di-Bernardo, 1992). Taeniophallus bilineatus can be distinguished from the other species by the number of ventral scales (> 140) (Di-Bernardo \& Lema, 1990), and the other species from this tribe can be identified by its cephalic and dorsal marks (Di-Bernardo, 1992; Di-Bernardo \& Lema, 1986).

\section{Tribe Imantodini Myers, 2011}

In the Itajaí Valley Imantodes cenchoa Linnaeus (1758) is the only representative species from this tribe (Bérnils et al., 2001). It can be distinguished from the other species by the following characters: brown saddle-shaped dorsal blotches outlined by a lighter halo and light brown background color. Dorsal rows in 19-17-17 or 17-17-17, 229-263 ventral scales, 141-173 subcaudal scales, and 8-12 infralabials (Missassi \& Prudente, 2015).

\section{Tribe Elapomorphini Jan, 1862}

Members of this tribe have cephalic shields fused, reduced eyes, and strengthened skulls due to fossorial habits (Ferrarezzi, 1993). In the Itajaí Valley, Phalotris reticulatus is the only representative species from this tribe (Bérnils et al., 2001). Specimens show dorsal scale rows 15-15-15; black head followed by a yellowish nuchal collar, the dorsal color background is red with three longitudinal black stripes, one in the vertebral zone, and the other two in the pleural zones. It has a black cloacal ring, the venter is yellowish, with black semilunar blotches (Quintela \& Loebmann, 2009).

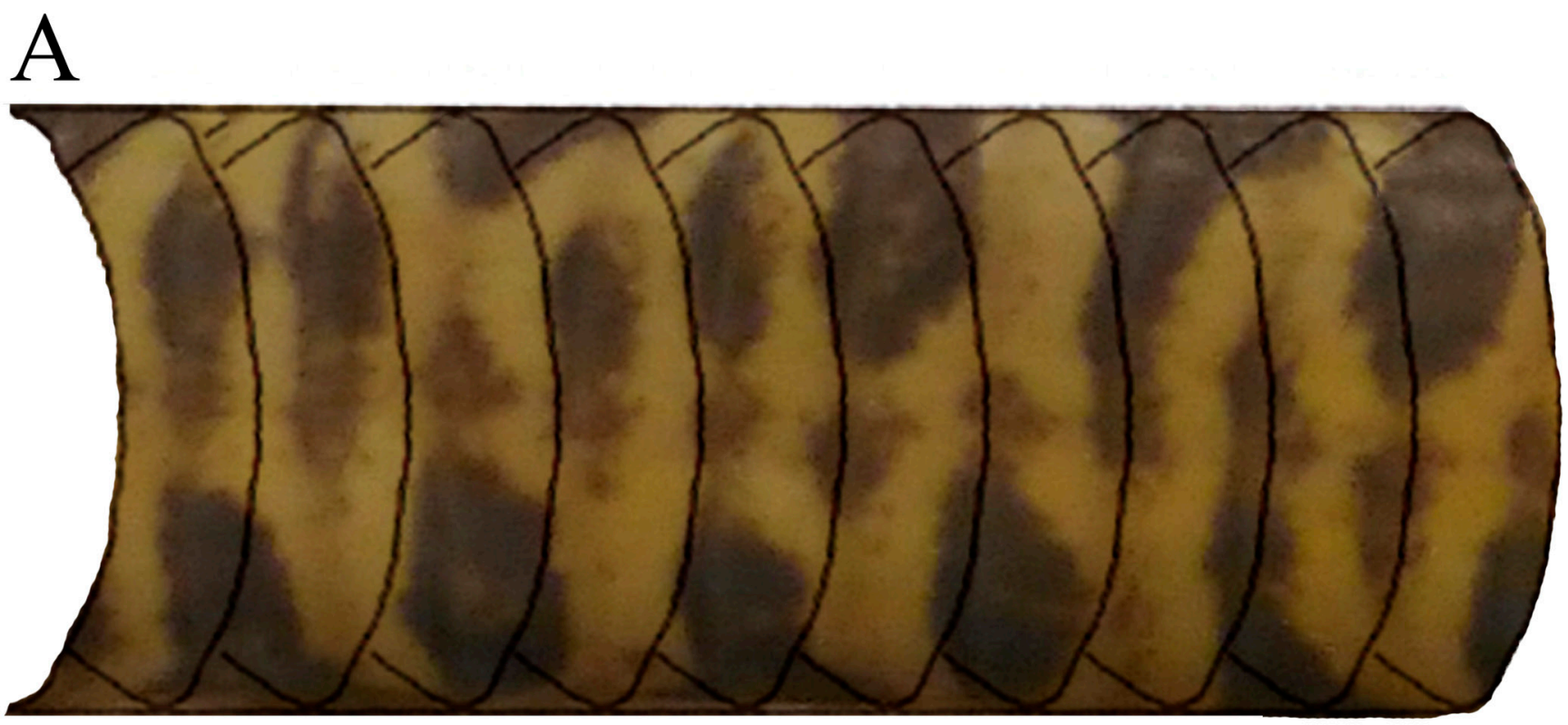

\section{$\mathrm{B}$}

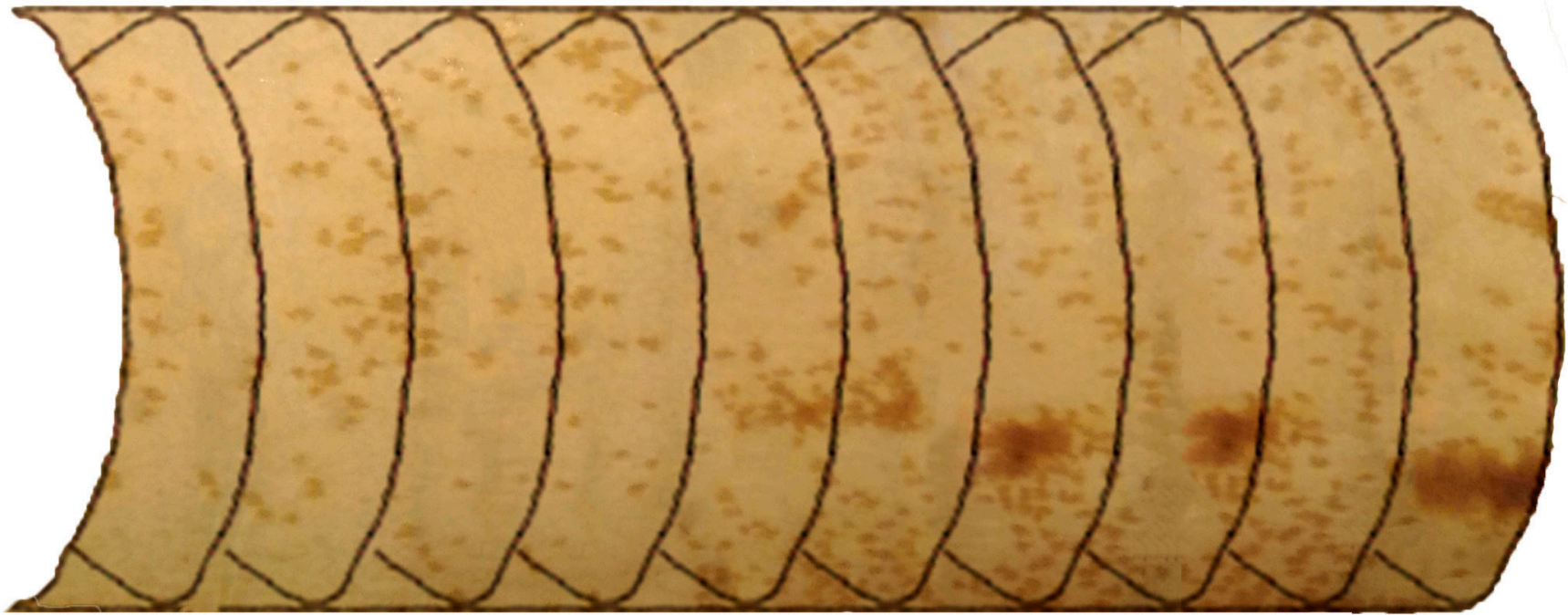

Figure 7. Comparative ventral view of: (A) Dipsas ventrimaculata (Boulenger, 1885) and (B) Dipsas neuwiedi (Ihering, 1911). 


\section{A}

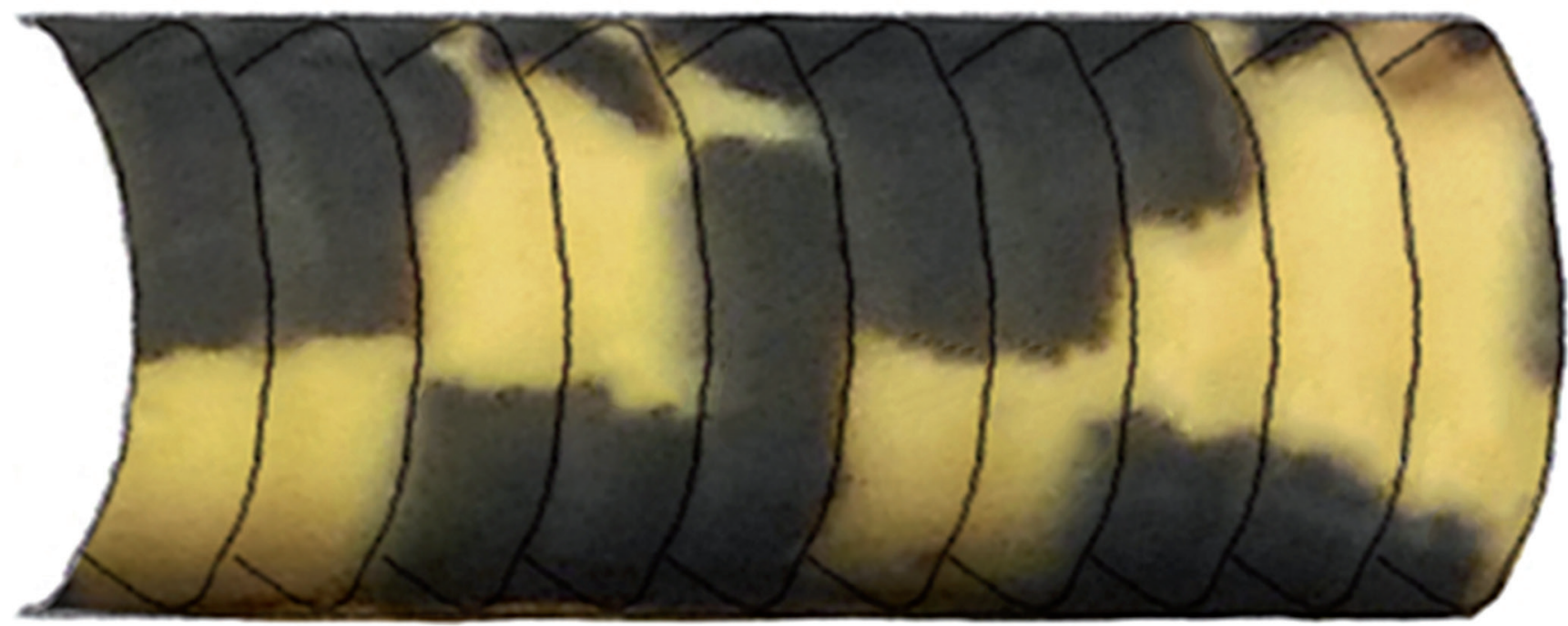

B

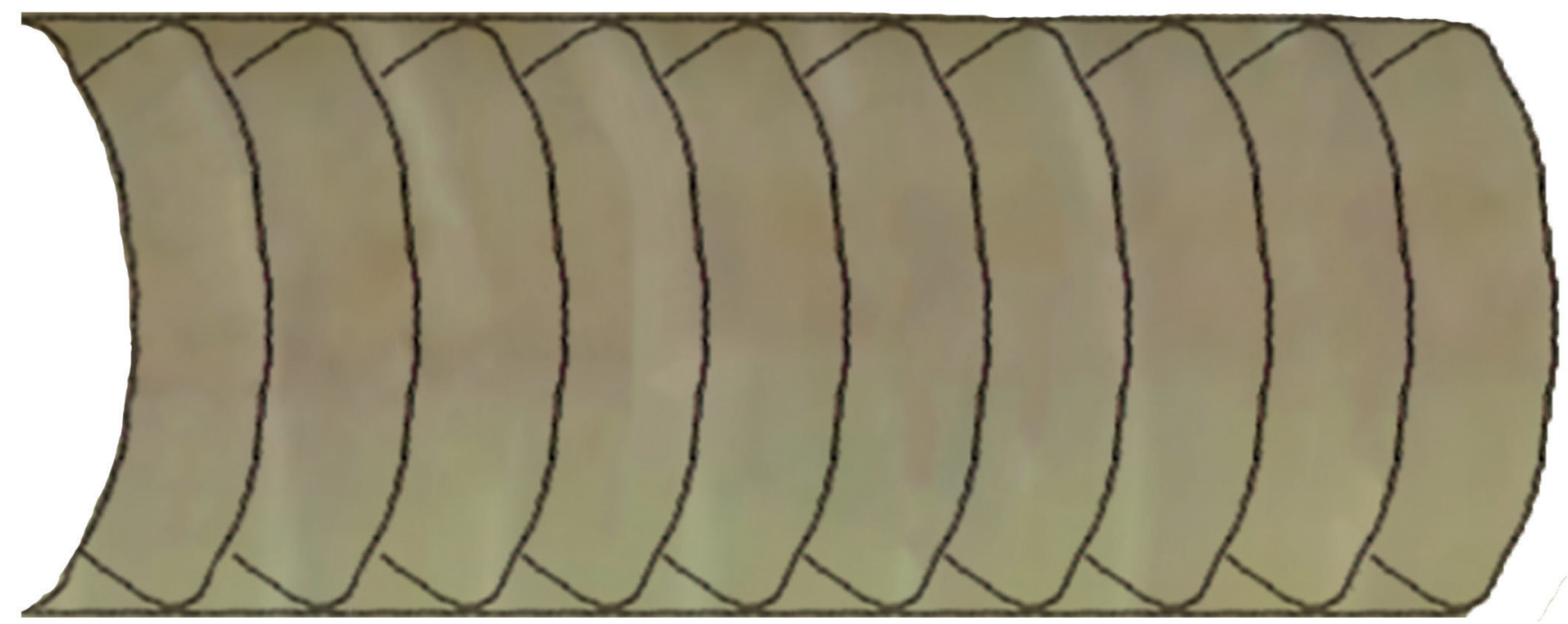

Figure 8. Comparative ventral view of: (A) Oxyrhopus clathratus Duméril, Bibron \& Duméril, 1854 and (B) Oxyrhopus rhombifer Duméril, Bibron \& Duméril, 1854.

\section{Tribe Tachymenini Bailey, 1967}

Members from this tribe usually have a small size, opisthoglyphous dentition, elliptical pupils, and a post-orbital stripe (Bailey, 1967). In the Itajaí Valley, Gomesophis, Thamnodynastes, and Tomodon are the representant genera from this tribe (Bérnils et al., 2001). Gomesophis brasiliensis has dorsal rows in 17-17-15, smooth scales with apical pits, and a brownish-green dorsal color, with stripes (Gonzalez et al., 2014). Species from the genus Thamnodynastes show dorsal pattern checkered anteriorly and dorsal rows in 19-19-15 (Franco et al., 2017). Finally, Tomodon dorsatus has 17 scale rows at mid-body (Harvey \& Muñoz, 2004), grey dorsal background color with dark marks, and black oral and cloacal mucosae (Quintela \& Loebmann, 2009).

\section{Tribe Pseudoboini Bailey, 1967}

Members of this tribe are oviparous, have smooth scales, bi-calyculate, and bi-capitate hemipenis (Bailey, 1967; Zaher, 1999; Zaher et al., 2009). In the Itajaí Valley, Clelia, Oxyrhopus, and Pseudoboa are the representant genera from this tribe (Bérnils et al., 2001). Specimens from the genus Clelia have medium to large size, elliptical pupil, single anal plate, and ontogenetic color variation (Morato et al., 2003). Pseudoboa individuals are morphologically similar to Clelia, but the difference relies on the subcaudals; In Pseudoboa the subcaudals are single, different from Clelia, that possess paired subcaudals (Zaher et al., 2008). Also, they have dorsal scales in 19 rows at mid-body (Zaher, 1996; Zaher et al., 2008). Oxyrhopus specimens can grow to medium size and show banded or melanic coloration patterns (Bernardo et al., 2012). They 
present 19 scale rows at mid-body (Quintela \& Loebmann, 2009), 7 or 8 supralabials, 7 to 10 infralabials single anal plate, and paired subcaudal scales (Bernardo et al., 2012).

\section{Tribe Xenodontini Bonaparte, 1845}

Members from this tribe have hemipenis with paired apical disks and without calyces and capitular grooves Zaher et al. (2009). In the Itajaí Valley, Erythrolamprus and Xenodon are the representant genera from this tribe (Bérnils et al., 2001). Both genera display body flattening as a defensive strategy (Fraga et al., 2013; Zaher et al., 2009). Erythrolamprus shows a great range of color patterns, that can be uniform (Dixon, 1987), striped (Dixon, 1983), and banded (Dixon, 1983). Xenodon species have triangular-shaped heads very protruded from the body (Chippaux, 1986), they also show a high level of polychromatism, specifically in Xenodon merremii (Cacciali, 2010).

\section{Family Viperidae Oppel, 1811}

This group is characterized by solenoglyphous dentition, presence of loreal pits (Campbell \& Lammar, 2004; Bernarde, 2014), keeled dorsal scales, and triangular head shape, covered by small scales (Peters \& Orejas-Miranda, 1970; Melgarejo, 2009).

\section{ACKNOWLEDGMENTS}

The authors are grateful for the access to zoological collections provided by Sérgio Luiz Althoff (Zoological Collection from the Universidade Regional de Blumenau, CZFURB), Julio Cesar de Moura Leite (Herpetological Collection from the Museu de História Natural Capão da Imbuia, MHCNI), Selvino Neckel de Oliveira (Herpetological Collection from Universidade Federal de Santa Catarina, CHUFSC), Guilherme Salgado Grittz and Omar Machado Entiauspe-Neto for suggestions in the scope. Finally, we thank the Universidade Regional de Blumenau (FURB) for the PIBIC/FURB scholarship to the first author. Also, this study was partially financed by the Coordenação de Aperfeiçoamento de Pessoal de Nível Superior - Brasil (CAPES) - Finance Code 001.

\section{AUTHORS' CONTRIBUTIONS}

C.S.W. and L.O.M.G. designed the study. C.S.W. performed the data collection and laboratory studies. C.S.W. prepared the manuscript. L.O.M.G. supervisioned the manuscript. All authors approved the final manuscript. Authors declare there are no conflicts of interest.

\section{REFERENCES}

Abegg, A.D.; Balestrin, R.L.; Schossler, M.; Toso, J. \& Ghizoni-Junior, I.R. 2016. Xenodon guentheri Boulenger 1894 (Squamata, Dipsadidae): New State
Record and Key to the Genus Xenodon in the State of Rio Grande do Sul, Southern Brazil. Boletín de La Sociedad Zoológica del Uruguay, 25(1): 72-84.

Abegg, A.D.; Entiauspe-Neto, 0.M.; Ortiz, F.R. \& Mario, C. 2017. Presence of loreal scale in Tomodon dorsatus (Serpentes: Dipsadidae). Boletim do Museu Biológico Mello Leitão, 39(1): 1-10.

Althoff, L.F. 2014. Representatividade da coleção científica de serpentes da Fundação Universidade Regional de Blumenau (FURB), com ênfase no Estado de Santa Catarina. (Monograph). Universidade Regional de Blumenau, Blumenau.

Amaral, A. 1929. Revisão do Genero Spilotes Wagler, 1830. Memórias do Instituto Butantan, 4: 275-305.

Aumond, J.A.; Sevegnani, L. \& Frank, B. 2018. Atlas Bacia do Itajaí: formação, recursos naturais e ecossistemas. Blumenau, EDIFURB.

Bailey, J.R. 1967. The Synthetic Approach to Colubrid Classification. Herpetologica, 23(2): 155-161.

Bailey, J.R.; Thomas, R.A. \& Silva, N.J. 2005. A revision of the South American snake genus Thamnodynastes Wagler, 1830 (Serpentes, Colubridae, Tachymenini). I. Two new species of Thamnodynastes from Central Brazil and adjacent areas, with a redefinition of and neotype designation for Thamnodynastes. Phyllomedusa, 4(2): 83-101.

Bellini, G.P.; Arzamendia, V. \& Giraudo, A.R. 2013. Ecology of Thamnodynastes hypoconia in Subtropical-Temperate South America. Herpetologica, 69(1): 67-79.

Bernarde, P.S. 2014. Serpentes peçonhentas e acidentes ofídicos no Brasil. São Paulo, Anolis Books Editora.

Bernardo, P.H.; Machado, F.A.; Murphy, R.W. \& Zaher, H. 2012. Redescription and Morphological Variation of Oxyrhopus clathratus Duméril, Bibron and Duméril, 1854 (Serpentes: Dipsadidae: Xenodontinae). South American Journal of Herpetology, 7(2): 134-148.

Bérnils, R.S.; Batista, M. \& Bertelli, P.W. 2001. Cobras e lagartos do Vale: levantamento das espécies de Squamata (Reptilia, Lepidosauria) da Bacia do Rio Itajaí, Santa Catarina, Brasil. Revista de Estudos Ambientais, 3(1): 69-79.

Cacciali, P. 2010. Chromatic variation in populations of Xenodon merremi (Serpentes: Dipsadidae) in Paraguay. Acta Herpetologica, 5(1): 107-112.

Campbell, J.A. \& Lammar, W.W. 2004. The venomous reptiles of the western hemisphere. Ithaca, Comstock Pub.

Chippaux, J. 1986. Les Serpents de la Guyane Française. Paris, Éditions de I'ORSTOM (Collection Faune Tropicale 27.

Costa, H.C. \& Bérnils, R.S. 2018. Répteis do Brasil e suas Unidades Federativas: Lista de espécies. Herpetologia Brasileira, 7(1): 1-58.

Costa, H.C.; Santana, D.J.; Leal, F.; Koroiva, R. \& Garcia, P.C.A. 2016. A New Species of Helicops (Serpentes: Dipsadidae: Hydropsini) from Southeastern Brazil. Herpetologica, 72(2): 157-166.

Di Nicola, M.R. 2019. A revised dichotomous key to the snakes of Italy (Reptilia, Squamata, Serpentes), according to recent systematic updates. Zootaxa, 4686(2): 294-296.

Di-Bernardo, M. 1992. Revalidation of The Genus Echinanthera Cope, 1894, and its Conceptual Amplification (Serpentes, Colubridae). Comunicações do Museu de Ciências da PUCRS, Série Zoologia, 5(13): 225-256.

Di-Bernardo, M. \& Lema, T. 1986. 0 gênero Rhadinaea Cope, 1863, no Brasil Meridional. Il. Rhadinaea persimilis (Cope, 1869) (Serpentes, Colubridae). Acta Biologica Leopoldensia, 8(1): 101-122.

Di-Bernardo, M. \& Lema, T. 1990. 0 gênero Rhadinaea Cope, 1863 no Brasil Meridional. IV. Rhadinaea bilineata (Fischer, 1885) (Serpentes, Colubridae). Acta Biologica Leopoldensia, 12(2): 359-392.

Di-Bernardo, M.; Borges-Martins, M. \& Silva-Jr., N.J. 2007. A new species of coralsnake (Micrurus: Elapidae) from southern Brazil. Zootaxa, 1447: $1-26$. 
Dixon, J.R. 1983. Systematics of the Latin American snake, Liophis epinephelus (Serpentes: Colubridae). In: Rhodin, A.G. \& Miyata, K. (Eds.). Advances in Herpetology and Evolutionary Biology. Museum of Comparative Zoology. Cambridge, University of Harvard. p. 132-149.

Dixon, J.R. 1987. Taxonomy and geographic variation of Liophis typhlus and related "green" species of South America (Serpentes: Colubridae). Annals of the Carnegie Museum, 56: 173-191.

Dixon, J.R. 1989. A key and checklist to the Neotropical snake genus Liophis with country lists and maps. Smithsonian Herpetological Information Service, 79: 1-40.

Dixon, J.R. \& Kofron, C.P. 1983. The Central and South American Anomalepid Snakes of the Genus Liotyphlops. Amphibia-Reptilia, 4(2): 241-264.

Dixon, J.R.; Wiest, J.A. \& Cei, J.M. 1993. Revision of the Neotropical Snake Genus Chironius Fitzinger (Serpentes, Colubridae). Torino, Museo Regionale Di Scienze Naturali. (Monografie № 13).

Dowling, H.G. 1951. A proposed method of expressing scale reductions in snakes. Copeia, 1951(2): 131-134.

Entiauspe-Neto, 0.M.; Lyra, M.L.; Koch, C.; Quintela, F.M.; Abegg, A.D. \& Loebmann, D. 2020. Taxonomic Revision of Chironius bicarinatus (Wied 1820) (Serpentes: Colubridae), with Description of a New Species. Herpetological Monographs, 34: 98-115.

Ferrarezzi, H. 1993. Nota sobre o gênero Phalotris com revisão do grupo Nasutus e descrição de três novas espécies (Serpentes, Colubridae, Xenodontinae). Memórias do Instituto Butantan, 55(1): 21-38.

Ferrarezzi, H. 1994. Uma sinopse dos gêneros e classificação das serpentes (Squamata): I.Scolecophidia e Alethinophidia não colubrídeos. In: Nascimento, L.B.; Bernardes, A.T. \& Cotta, G.A. (Eds.). Herpetologia no Brasil, 1. Belo Horizonte, Sociedade Brasileira de Herpetologia. p. 69-80.

Ferrarezzi, H. \& Monteiro, A.E.G. 2001. Chave para Determinação de Gênero de Serpentes Sul-Americanas. Available: https://pt.scribd.com/ document/220549202/Chave-Serpentes-Ferrarezzi-Monteiro-11. Access: 07/09/2020.

Fortes, V.B.; Lucas, E.M. \& Caldart, V.M. 2010. Reptilia, Serpentes, Dipsadidae, Gomesophis brasiliensis (Gomes, 1918): Distribution extension in state of Santa Catarina, Brazil. Check List, 6(3): 414-415.

Fraga, R.; Lima, A.P.; Prudente, A.L.C. \& Magnusson, W.E. 2013. Guia de cobras da região de Manaus - Amazônia Central. Manaus, INPA - Instituto Nacional de Pesquisas da Amazônia.

Franco, F.L. \& Ferreira, T.G. 2013. Descrição de uma nova espécie de Thamnodynastes Wagler, 1830 (Serpentes, Colubridae) do nordeste brasileiro, com comentários sobre o gênero. Phyllomedusa: Journal of Herpetology, 1(2): 57-74.

Franco, F.L.; Trevine, V.C.; Montingelli, G.G. \& Zaher, H. 2017. A new species of Thamnodynastes from the open areas of central and Northeastern Brazil (Serpentes: Dipsadidae: Tachymenini). Salamandra, 53(3): 339-350.

Girard, C. 1858. Descriptions of some new Reptiles collected by the US. Exploring Expedition under the command of Capt. Charles Wilkes, U.S.N. Third Part. Proceedings of the Academy of Natural Sciences of Philadelphia, 9: 181-182.

Gonzalez, R.C.; Prudente, A.L.C. \& Franco, F.L. 2014. Morphological variation of Gomesophis brasiliensis and Ptychophis flavovirgatus (Serpentes, Dipsadidae, Xenodontinae). Salamandra, 50(2): 85-98.

Harvey, M.B. \& Muñoz, A. 2004. A new species of Tomodon (Serpentes: Colubridae) from high elevations in the bolivian Andes. Herpetologica, 60(3): 364-372.

Hoge, A.R. 1957. Étude Sur Uromacerina ricardinii (Peracca) (Serpentes). Memórias do Instituto Butantan, 27: 77-82.

Hoogmoed, M.S.; Fernandes, R.; Kucharzewski, C.; Moura-Leite, J.C.; Bérnils, R.S.; Entiauspe-Neto, 0.M. \& Santos, F.P.R. 2019. Synonymization of Uromacer ricardinii Peracca, 1897 with Dendrophis aurata Schlegel,
1837 (Reptilia: Squamata: Colubridae: Dipsadinae), a Rare South American Snake with a Disjunct Distribution. South American Journal of Herpetology, 14(2): 88-102.

Kunz, T.S.; Ghizoni-Junior, I. \& Giasson, L.0.M. 2011. Novos registros de répteis para as áreas abertas naturais do planalto e do litoral sul de Santa Catarina, Brasil. Biotemas, 24(3): 129-141.

Melgarejo, A.R. 2009. Serpentes peçonhentas do Brasil. In: Cardoso, J.L.C.; França, O.S.E.; Wen, F.H.; Málaque, C.M.S. \& Haddad-Jr., V. (Orgs.). Animais Peçonhentos no Brasil: biologia, clínica eterapêutica dos acidentes. 2.ed. São Paulo, Sarvier.

Missassi, A.F.R. \& Prudente, A.L.C. 2015. A new species of Imantodes Duméril, 1853 (Serpentes, Dipsadidae) from the Eastern Cordillera of Colombia. Zootaxa, 3980(4): 562-574.

Montingelli, G.G.; Grazziotin, F.G.; Battilana, J.; Murphy, R.W.; Zhang, Y. \& Zaher, H. 2019. Higher-level phylogenetic affinities of the Neotropical genus Mastigodryas Amaral, 1934 (Serpentes: Colubridae), speciesgroup definition and description of a new genus for Mastigodryas bifossatus. Journal of Zoological Systematics and Evolutionary Research, 57(2): 205-239.

Morato, S.A.A.; Franco, F.L. \& Sanches, E.J. 2003. Uma nova espécie de Clelia (Serpentes, Colubridae) do sul do Brasil. Phyllomedusa: Journal of Herpetology, 2(2): 93-100.

Nogueira, C.C.; Argôlo, A.J.S.; Arzamendia, V.; Azevedo, J.A.; Barbo, F.E.; Bérnils, R.S.; Bolochio, B.E.; Borges-Martins, M.; Brasil-Godinho, M.; Braz, H.; Buononato, M.A.; Cisneros-Heredia, D.F.; Colli, G.R.; Costa, H.C.; Franco, F.L.; Giraudo, A.; Gonzalez, R.C.; Guedes, T.; Hoogmoed, M.S.; Marques, O.A.V.; Montingelli, G.G.; Passos, P.; Prudente, A.L.C.; Rivas, G.A.; Sanchez, P.M.; Serrano, F.C.; Silva, N.J.; Strüssmann, C.; Vieira-Alencar, J.P.S.; Zaher, H.; Sawaya, R.J. \& Martins, M. 2020. Atlas of Brazilian Snakes: verified point-locality maps to mitigate the Wallacean shortfall in a megadiverse snake fauna. South American Journal of Herpetology, 14(sp1): 1-274.

Oliveira, S.N.; Kunz, T.; Rocha, V.C.; Rocha, A.P.; Rosa, A.; Oliveira, C.A.T. \& Sebben, A. 2020. Ofidismo em Santa Catarina: Identificação, prevenção de acidentes e primeiros socorros. Florianópolis, Universidade Federal de Santa Catarina.

Papavero, N. 1994. Fundamentos práticos de taxonomia zoológica (Coleções, Bibliografia, Nomenclatura). 2.ed. São Paulo, Editora UNESP.

Passos, P.; Fernandes, R. \&Zanella, N. 2005. A New Species of Atractus (Serpentes: Colubridae) from Southern Brazil. Herpetologica, 61(2): 209-218.

Passos, P.; Fernandes, R.; Bérnils, R.S. \& De Moura-Leite, J.C. 2010. Taxonomic revision of the Brazilian Atlantic Forest Atractus (Reptilia: Serpentes: Dipsadidae). Zootaxa, 2364: 1-63.

Passos, P.; Mueses-Cisneros, J.J.; Lynch, J.D. \& Fernandes, R. 2009. Pacific lowland snakes of the genus Atractus (Serpentes: Dipsadidae), with description of three new species. Zootaxa, 2293: 1-34.

Peters, J.A. 1960. The snakes of the subfamily Dipsadinae. Miscellaneous Publications Museum of Zoology, University of Michigan, 1114: 1-224.

Peters, J.A. \& Orejas-Miranda, B.R. 1970. Catalogue of the Neotropical Squamata: Part I. Snakes. Bulletin. United States National Museum of the, 297: 1-347.

Quintela, F.M. \& Loebmann, D. 2009. Guia ilustrado: os répteis da região costeira do Extremo Sul do Brasil. Pelotas, USEB.

Rasmussen, A.R.; Elmberg, J.; Gravlund, P. \& Ineich, I. 2011. Sea snakes (Serpentes: Subfamilies Hydrophiinae and Laticaudinae) in Vietnam: A comprehensive checklist and an updated identification key. Zootaxa, 20(2894): 1-20.

Schaefer, E.F. \& Alvarez, B.B. 1999. Caracterización de Liophis poecilogyrus (Wied) (Serpentes: Colubridae) en Argentina, Paraguay y Uruguay. In: Reunion de Comunicaciones Cientificas y Tecnologicas, 130. Corrientes, Universidad Nacional del Nordeste. p. 1-4. 
Sueiro, L.R.; Rojas, C.A.; Risk, J.Y.; França, F.O.S. \& Almeida-Santos, S.M. 2010. Anomalias cromáticas em Bothrops jararaca (Serpentes, Viperidae): Xantismo interfere na sobrevivência? Biotemas, 23(1): 155-160.

Thomas, R.A. \& J.R. Dixon. 1977. A new systematic arrangement for Philodryas serra (Schlegel) and Philodryas pseudoserra Amaral (Serpentes, Colubridae). The Pearce-Sellards Series, 27: 1-20.

Uetz, P.; Freed, P. \& Hošek, J. (Eds.). 2020. The Reptile Database. Available: http://www.reptile-database.org. Access: 07/09/2020.

Vanzolini, P.E. 1980. Répteis das Caatingas. Rio de Janeiro, Academia Brasileira Ciências Publicas.

Zaher, H. 1996. A New Genus and Species of Pseudoboine Snake, with a revision of the genus Clelia (Serpentes, Xenodontinae). Bolletino Del Museo Regionale Di Scienze Naturali, 14(2): 289-337.

Zaher, H. 1999. Hemipenial morphology of the South American xenodontine snakes, with a proposal for a monophyletic Xenodontinae and a reappraisal of colubroid hemipenes. Bulletins of American Museum of Natural History, 240: 1-168.

Zaher, H.; Grazziotin, F.G; Cadle, J.E.; Murphy, R.W.; De Moura-Leite, J.C. \& Bonatto, E.S.L. 2009. Molecular phylogeny of advanced snakes (Serpentes, Caenophidia) with an emphasis on South American xenodontines: a revised classification and description of new taxa. Papéis Avulsos de Zoologia, 49: 115-153.

Zaher, H.; Murphy, R.W.; Arredondo, J.C.; Graboski, R.; Machado-Filho, P.R.; Mahlow, K., Montingelli, G.G.; Quadros, A.B.; Orlov, N.L.; Wilkinson, M.; Zhang, Y.P. \& Grazziotin, F.G. 2019. Large-scale molecular phylogeny, morphology, divergence-time estimation, and the fossil record of advanced caenophidian snakes (Squamata: Serpentes). PLOS ONE, 14(5): e0216148.

Zaher, H.; Oliveira, M. \& Franco, F. 2008. A new, brightly colored species of Pseudoboa Schneider, 1801 from the Amazon. Zootaxa, 37: 27-37. 


\section{APPENDIX I}

Table 1. Literature used for the species identifications.

\begin{tabular}{|c|c|}
\hline Species & Bibliography \\
\hline \multicolumn{2}{|r|}{ Anomalepididae } \\
\hline Liotyphlops beui & Dixon \& Kofron (1983) \\
\hline \multicolumn{2}{|r|}{ Colubridae } \\
\hline Chironius bicarinatus & Dixon et al. (1993); Entiauspe-Neto et al. (2020) \\
\hline Chironius exoletus & Dixon et al. (1993) \\
\hline Chironius foveatus & Dixon et al. (1993) \\
\hline Chironius laevicollis & Dixon et al. (1993) \\
\hline Palusophis bifossatus & Montingelli et al. (2019) \\
\hline Spilotes pullatus & Amaral (1929) \\
\hline \multicolumn{2}{|r|}{ Dipsadidae } \\
\hline Atractus reticulatus & Passos et al. (2005); Passos et al. (2010) \\
\hline Clelia plumbea & Zaher (1996) \\
\hline Dipsas albifrons & Peters \& Orejas-Miranda (1970) \\
\hline Dipsas neuwiedi & Peters \& Orejas-Miranda (1970); Quintela \& Loebmann (2009) \\
\hline Dipsas ventrimaculata & Peters \& Orejas-Miranda (1970); Quintela \& Loebmann (2009) \\
\hline Echinantera cyanopleura & Di-Bernardo (1992) \\
\hline Echinantera undulata & Di-Bernardo (1992) \\
\hline Erythrolamprus almadensis & Dixon (1983); Dixon (1987); Quintela \& Loebmann (2009) \\
\hline Erythrolamprusjaegeri & Dixon (1983); Dixon (1987); Quintela \& Loebmann (2009) \\
\hline Erythrolamprus miliaris & Dixon (1983); Dixon (1987); Quintela \& Loebmann (2009) \\
\hline Erythrolamprus poecilogyrus & Schaefer \& Alvarez (1999); Quintela \& Loebmann (2009) \\
\hline Gomesophis brasiliensis & Gonzalez et al. (2014) \\
\hline Helicops carinicaudus & Costa et al. (2016) \\
\hline Helicops infrataeniatus & Costa et al. (2016) \\
\hline Imantodes cenchoa & Missassi \& Prudente (2015) \\
\hline Oxyrhopus clathratus & Bernardo et al. (2012) \\
\hline Oxyrhopus rhombifer & Quintela \& Loebmann (2009) \\
\hline Phalotris reticulatus & Ferrarezzi, (1993); Quintela \& Loebmann (2009) \\
\hline Philodryas aestiva & Vanzolini, 1980; Quintela \& Loebmann (2009) \\
\hline Philodryas olfersii & Vanzolini, 1980; Quintela \& Loebmann (2009) \\
\hline Philodryas patagoniensis & Vanzolini, 1980; Quintela \& Loebmann (2009) \\
\hline Pseudoboa haasi & Zaher (1996) \\
\hline Taeniophallus bilineatus & Di-Bernardo \& Lema, (1990); Di-Bernardo (1992) \\
\hline Taeniophallus persimilis & Di-Bernardo \& Lema, (1986); Di-Bernardo, (1992) \\
\hline Thamnodynastes strigatus & Bellini et al. (2013); Franco \& Ferreira (2013) \\
\hline Thamnodynastes hypoconia & Bailey et al. (2005); Bellini et al. (2013); Franco \& Ferreira (2013) \\
\hline Tomodon dorsatus & Harvey \& Muñoz (2004); Quintela \& Loebmann (2009); Abegg et al. (2017) \\
\hline Tropidodryas serra & Thomas \& Dixon (1977) \\
\hline Tropidodryas striaticeps & Thomas \& Dixon (1977) \\
\hline Dendrophis aurata & Hoge (1957); Hoogmoed et al. (2019) \\
\hline Xenodon guenteri & Quintela \& Loebmann (2009); Abegg et al. (2016) \\
\hline Xenodon merremii & Peters \& Orejas-Miranda (1970); Quintela \& Loebmann (2009) \\
\hline Xenodon neuwiedii & Quintela \& Loebmann (2009); Abegg et al. (2016) \\
\hline \multicolumn{2}{|r|}{ Elapidae } \\
\hline Micrurus altirostris & Di-Bernardo et al. (2007) \\
\hline Micrurus corallinus & Di-Bernardo et al. (2007) \\
\hline \multicolumn{2}{|r|}{ Viperidae } \\
\hline Bothrops jararaca & Bernarde (2014) \\
\hline Bothrops jararacussu & Bernarde (2014) \\
\hline Bothrops neuwiedi & Bernarde (2014) \\
\hline Crotalus durissus & Bernarde (2014) \\
\hline
\end{tabular}




\section{APPENDIX II}

\section{Specimens examined}

Liotyphlops beui $(\mathrm{n}=5)$

BRAZIL: Santa Catarina: São Domingos (FURB 11527; 11575; 11654; 21009; 21010).

Chironius bicarinatus $(\mathrm{n}=10)$

BRAZIL: Santa Catarina: Abdon Batista (FURB 11988; 21049); Alfredo Wagner (CHUFSC 788); Blumenau (FURB 2736; 2804;); Curitibanos (FURB 21182); Indaial (FURB 2121; 2833); São Domingos (FURB 2894); Vidal Ramos (CHUFSC 898).

Chironius exoletus $(\mathrm{n}=10)$

BRAZIL: Santa Catarina: Biguaçu (FURB 21574); Blumenau (FURB 2805; 2989; 11247; 21188); Gaspar (FURB 2604; 11175); Major Gersino (FURB 11307); Not cataloged (FURB 21467); São José (21519).

Chironius foveatus $(n=6)$

BRAZIL: Santa Catarina: Blumenau (FURB 2157; 2785; 2878; 3000; 11136; 11341).

Chironius laevicollis $(\mathbf{n}=\mathbf{1 0})$

BRAZIL: Santa Catarina: Antônio Carlos/São Pedro de Alcântara (CHUFSC 884); Blumenau (FURB 2619; 21463); Gaspar (FURB 2213; 2869); Ilhota (FURB 21488); Major Gersino (11547); São José (FURB 21515); Timbó (FURB 2816; 2817).

Palusophis bifossatus $(\mathrm{n}=6)$

BRAZIL: Paraná: Carambeí (MHNCI 11240; 11760); Guaíra (MHNCI 642; 717); Mandaguari (MHNCI 4620); Santa Catarina: Garopaba (MHNCI 717).

Spilotes pullatus $(\mathrm{n}=10)$

BRAZIL: Santa Catarina: Blumenau (FURB 2143; 2198; FURB 2211; 2529; 2774; FURB 2784; 11010; 11060); São José (FURB 21514); Vidal Ramos (FURB 11452 ).

Dendrophis aurata $(\mathrm{n}=3)$

BRAZIL: Paraná: Morretes (MHNCI 672); Pontal Paraná (MHNCI 2180); Santa Catarina: Blumenau (FURB 2156).

Atractus reticulatus $(\mathrm{n}=3)$

BRAZIL: Santa Catarina: São José do Cerrito (FURB 21001; 21002; 21003).

Dipsas albifrons $(\mathrm{n}=\mathbf{1 0})$

BRAZIL: Santa Catarina: Blumenau (FURB 2101; 2155; 2162; 2678; 2719; 2829; 2858; Gaspar (FURB 11173); Jaraguá do Sul (FURB 2078); Santo Amaro da Imperatriz (CHUFSC 649).

Dipsas neuwiedi $(\mathrm{n}=10)$

BRAZIL: Santa Catarina: Biguaçú (FURB 21462); Blumenau (FURB 2141; 2220; 2542; 2747; 2752; 2783; 2794; Brusque (FURB 21506); Luis Alves (FURB 11160$).$

Dipsas ventrimaculatus $(\mathrm{n}=10)$

BRAZIL: Santa Catarina: Chapecó (CHUFSC 1104; 1444); Passos Maia (FURB 11316); Santa Catarina/Rio Grande do Sul: Águas de Chapecó/Paial/Alpestre/Itatiba do Sul (FURB 11782; 11785; 11798; 11847; 11856; 11857; 1937).

Echinanthera cyanopleura $(\mathrm{n}=4)$

BRAZIL: Santa Catarina: Abdon Batista (FURB 21065) Blumenau (FURB 2674; 2697; 11225).

Echinanthera undulata $(n=4)$

BRAZIL: Santa Catarina: Blumenau (FURB 2623); Gaspar (FURB 21536); São Bento do Sul (FURB 21185); Timbó (11572).

Taeniophallus bilineatus $(\mathrm{n}=10)$

BRAZIL: Santa Catarina: Blumenau (FURB 2086; 2675; 2849; 11036; 21507; Doutor Pedrinho (FURB 21496); Gaspar (FURB 11183); Ibirama (FURB 21484); Timbó (FURB 21497);Vargem/São José do Cerrito (FURB 21091).

Taeniophallus persimilis $(\mathrm{n}=2)$

BRAZIL: Paraná: Guaratuba (MHNCI 835); Tijucas do Sul (MHNCI 60611).

Phalotris reticulatus $(\mathrm{n}=2)$

BRAZIL: Santa Catarina: Araranguá (MHNCI 3149); Palhoça (CHUFSC 3216). 


\section{Helicops carinicaudus $(\mathrm{n}=5)$}

BRAZIL: Santa Catarina: Chapecó (FURB 21172); Gaspar (FURB 2537; 11943); Itajaí (FURB 21138); Itapoá (FURB 11587).

\section{Helicops infrataeniatus $(\mathrm{n}=6)$}

BRAZIL: Santa Catarina: Abdon Batista (FURB 21048; 21068); Capão Alto (FURB 21118); São Domingos (FURB 11220; 21058); Vargem/São José do Cerrito (FURB 21090).

Imantodes cenchoa $(\mathbf{n}=\mathbf{3})$

BRAZIL: Santa Catarina: Blumenau (FURB 2679; 11054); Gaspar (FURB 11168).

\section{Clelia plumbea $(\mathrm{n}=4)$}

BRAZIL: Santa Catarina: Florianópolis (CHUFSC 49; 271; 526; 653).

\section{Oxyrhopus clathratus $(\mathrm{n}=10)$}

BRAZIL: Santa Catarina: Blumenau (FURB 2036; 2153; 2154; 2680; 2690; 2744; 2777; 21522; 21545); Gaspar (FURB 21178).

\section{Oxyrhopus rhombifer $(\mathrm{n}=6)$}

BRAZIL: Rio Grande do Sul: Alpestre (FURB 11360); Faxinalzinho (CHUFSC 1272); Santa Catarina: Campos Novos (FURB CHUFSC 3839), Guatambu (CHUFSC 1172); Palhoça (CHUFSC 3210) São Joaquim (FURB 21640).

\section{Pseudoboa haasi $(\mathrm{n}=6)$}

BRAZIL: Paraná: Carambeí (MHNCl 11766); Catanduvas (MHNCI 8481); Piraí do Sul (MHNCl 14412); Pituruna (MHNCl 14432); Reserva do Iguaçú (MHNCI 5355 ); Santa Catarina: Joinville (FURB 21505).

Philodryas aestiva $(\mathrm{n}=10)$

BRAZIL: Santa Catarina: Água Doce (CHUFSC 615); Alfredo Wagner (CHUFSC 074); Bom Retiro (CHUFSC 1096); Florianópolis (CHUFSC 068; 073; 454; 685); Ipuaçu (CHUFSC 676); Palhoça (CHUFSC 2702).

Philodryas olfersii $(\mathrm{n}=10)$

BRAZIL: Rio Grande do Sul: Estrela (FURB 21142); Santa Catarina/Rio Grande do Sul: Águas de Chapecó/Paial/Alpestre/Itatiba do Sul (FURB 11753; 11759; 11767); Santa Catarina: Guatambu (FURB 11290); Itá (FURB 2574); São Domingos (FURB 2945; 2946; 2947; 11197).

\section{Philodryas patagoniensis $(\mathrm{n}=10)$}

BRAZIL: Santa Catarina: Abdon Batista (FURB 21047; 21052); Abdon Batista/Anita Garibaldi (FURB 21061); Alfredo Wagner (CHUFSC 1371); Anita Garibaldi (FURB 21062); Florianópolis (CHUFSC 556; 559); Jaguaruna (CHUFSC 1050); São José (CHUFSC 1154); Vargem/São José do Cerrito (FURB 21094).

\section{Gomesophis brasiliensis $(\mathrm{n}=10)$}

BRAZIL: Paraná: Curitiba (MHNCI 745; 14342); Guarapuava (MHNCI 3308); Piraí do Sul (MHNCI 14406); Piraquara (MHNCI 7289; 11793 ); São Mateus do Sul (MHNCI 1340); União da Vitória (MHNCl 4739); Santa Catarina: Caçador (MHNCl 10062); São José dos Pinhais (MHNCl 595).

\section{Thamnodynastes hypoconia $(\mathrm{n}=8)$}

BRAZIL: Rio Grande do Sul/Santa Catarina: Águas de Chapecó/Paial/Alpestre/Itatiba do Sul (FURB 11778); Santa Catarina: Doutor Pedrinho (FURB 21023; 21024); Guaratuba (FURB 21081); Passos Maia (FURB 21045); São Domingos (FURB 2632; 11219; 11457).

\section{Thamnodynastes strigatus $(\mathrm{n}=10)$}

BRAZIL: Rio Grande do Sul: Aratiba (CHUFSC 1286); Santa Catarina: Abdon Batista (FURB 21057); Curitibanos (FURB CHUFSC 3791); Ipuaçu (FURB 2640); São Domingos (FURB 2897; 2898; 2899; 2900; 2902; 11218).

\section{Tomodon dorsatus $(\mathrm{n}=10)$}

BRAZIL: Santa Catarina: Arvoredo (FURB 11438); Anitápolis (FURB 11437); Doutor Pedrinho (FURB 11577); Faxinal do Guedes (FURB 11232); São Domingos (FURB 11319; 11321); Tangará (FURB 11562); Timbó (FURB 2835; 2836); Vargem/São José do Cerrito (FURB 21088).

Tropidodryas serra $(\mathrm{n}=10)$

BRAZIL: Santa Catarina: Florianópolis (CHUFSC 385; 487; 541; 561; 586; 626; 719; 818); Porto Belo (CHUFSC 1367); São José (CHUFSC 473).

\section{Tropidodryas striaticeps $(\mathbf{n}=\mathbf{8})$}

BRAZIL: Santa Catarina: Antonio Carlos (CHUFSC 194; 820); Blumenau (FURB 2081; 2163; 2192; 2217; 2627; 2773).

\section{Erythrolamprus almadensis $(\mathrm{n}=5)$}

BRAZIL: Mato Grosso: Dois Irmãos do Buriti (MHNCI 7888); Paraná: Araucária (MHNCI 3675); Ponta Grossa (MHNCI 4440); Salvador (MHNCI 11347); São Paulo: Estado de São Paulo (MHNCl 7572). 


\section{Erythrolamprusjaegeri $(\mathrm{n}=9)$}

BRAZIL: Paraná: Campo Largo (MHNCI 8131); Curitiba (MHNCI 3759; 9170; 10141); Fazenda Rio Grande (MHNCI 11039; 11062); Guarapuava (MHNCI 10028); Quatro Barras (MHNCl 9236); Tijucas do Sul (MHNCl 7542).

\section{Erythrolamprus miliaris $(\mathrm{n}=10)$}

BRAZIL: Santa Catarina: Biguaçú (FURB 21455); Blumenau (FURB 2165; 2673; 2859; 11059; 21190; 21477); Gaspar (FURB 21501); Itapoá (CHUFSC 1236); Unknown locality (FURB 21111).

\section{Eryhrolamprus poecilogyrus $(\mathrm{n}=10)$}

BRAZIL: Santa Catarina: Abdon Batista (FURB 21050); Caxambu do Sul (FURB 11550); Chapecó (FURB 11551); Ipuaçu (FURB 2644; 2895); São Domingos (FURB 2554; $11212 ; 11213 ; 11214 ; 11222)$.

\section{Xenodon guentheri $(\mathrm{n}=10)$}

BRAZIL: Paraná: São José dos Pinhais (MHNCI 11737); União da Vitória (MHNCI 1605; 1761; 3994); Santa Catarina: Bom Jardim da Serra (CHUFSC 077; 087); Bom Retiro (CHUFSC 3436); Lages (CHUFSC 269; 474); São Cristóvão do Sul (MHNCI 744).

\section{Xenodon merremii $(\mathrm{n}=10)$}

BRAZIL: Paraná: Agudos do Sul (MHNCI 2167; 2216; 2217); Campina Grande do Sul (MHNCI 2212); Maringá (MHNCI 3582); Piraquara (MHNCI 2829); São José dos Pinhais (MHNCI 3441); Telêmaco Borba (MHNCI 2444; 2981); Umuarama (MHNCI 3964).

\section{Xenodon neuwiedi $(\mathrm{n}=10)$}

BRAZIL: Santa Catarina: Blumenau (FURB 2209; 2718; 2775; 2807; 2824; 11126; 11128; 21498); Corupá (FURB 21020); Indaial (FURB 2564).

\section{Micrurus altirostris $(\mathrm{n}=10)$}

BRAZIL: Rio Grande do Sul/Santa Catarina: Águas de Chapecó/Paial/Alpestre/Itatiba do Sul (FURB 11772; 11773); Santa Catarina: Chapecó (FURB 11478; 11519; 11520); Guatambu (FURB 11291; 11479; 11480); Rio dos Índios (FURB 11451); São Domingos (FURB 21027).

\section{Micrurus corallinus $(\mathrm{n}=10)$}

BRAZIL: Santa Catarina: Blumenau (FURB 2123; 2534; 2664; 2871; 11172; 11251; 11337; 21136; Indaial (FURB 21511); Pomerode (FURB 21510).

\section{Bothrops jararaca $(\mathrm{n}=10)$}

BRAZIL: Santa Catarina: Arvoredo (FURB 11434); Blumenau (FURB 2185; 2199; 2713; 2806; 2877; 2883; 11144; 21030); Ipuaçu (FURB 2889).

\section{Bothrops jararacussu $(\mathrm{n}=10)$}

BRAZIL: Santa Catarina: Blumenau (FURB 2123; 2149; 2527; 2530; 2628; 2867; 2872; 11747); Brusque (FURB 2038); Gaspar (FURB 2618).

\section{Bothrops neuwiedi $(\mathrm{n}=2)$}

BRAZIL: Paraná: Palmas (FURB 11264); Rio Grande do Sul/Santa Catarina: Áquas de Chapecó/Paial/Alpestre/ltatiba do Sul (FURB 11843).

Crotalus durissus $(\mathrm{n}=6)$

BRAZIL: Minas Gerais: Nova Ponte (FURB 11736; 11737); Santa Catarina: Ipuaçu (FURB 2605; 11135); São Domingos (FURB 11565; 21026). 